\title{
Designing Multiple Book Clubs to Meet the Interest of Diverse Populations
}

\author{
Kathy Hicks-Brooks \\ Media Specialist \\ Ben Davis High School \\ Metropolitan School District of Wayne Township \\ USA
}

\begin{abstract}
Reading for recreation has been an on-going problem for our high school so we decided to create an after-school book club. However, in large urban high schools with diverse populations, it is difficult to meet the interest of all students with one book club.
\end{abstract}

In our school there are fifty-two languages represented and students from various backgrounds, ethnicities and academic abilities.

Data was collected, analyzed and a question emerged. If we developed book clubs around the interest of students, would recreational reading activities increase at our high school? The following paper is what we found to be the answer.

Book Clubs, High Schools, Diversity

\section{Background}

It does no good to have a beautiful media center, up-to date collections, and computers capable of handling gigabytes of information, if no one ever uses it. Books that lay in wait while onlookers pass by hurriedly on their way to somewhere else do nothing for the academic achievement of students at any school. Creating exciting programs such as book clubs, not only promotes the media center, but it is a great way to encourage students to read for recreation.

One way to improve reading comprehension is to give students the opportunity (practice) to read for leisure. Book clubs give students the opportunity to read, and they also match students with other students who enjoy reading similar genres. But what if a school has students from various backgrounds, ethnicities, and academic abilities? Our urban district, MSD of Wayne Township, has students who speak fifty-two different languages representing different ethnicities. We have students from China, Vietnam, Malawi, Ghana, Ethiopia, Japan, Peru , El Salvador, the Philippines, India, Somalia, Liberia, Honduras, Mexico, Sudan and many other countries.

Ben Davis High School has approximately 3,050 students in grades 10-12. There is a separate ninth grade center. According to the Indiana Department of Education's website, Ben Davis High School's student make up is 52\% Caucasian, 33\% Black, 9\% Hispanic, 2\% Asian, and 4\% multi-racial. Fifty-three percent of the students are on free or reduced school lunch. Of these students, 54\% passed the reading portion of the Indiana Accountability System for Academic Progress Test (ISTEP) in the 2006-2007 school year. There was a slight increase this past year to $55 \%$. The goal would be to have $100 \%$ rate of students 
passing the ISTEP, however, a more realistic goal would be to have an annual increase of two to three percent.

What do all of these students have in common? Most of these students do not read for recreation. They only read what is assigned by their teachers. How do we encourage recreational reading and meet the needs of this diverse group? The high school already offers a variety of courses and diplomas. We offer both the Core 40 and honors diploma, and the International Baccalaureate (IB) diploma will be offered starting next school year. Students may take courses in radio and television, hair design, auto body or auto mechanics, culinary arts, desktop publishing, photography, ceramics, Spanish, French, or Latin, as well as core courses like English, geometry, and physics, just to name a few. Twenty-six AP classes are also offered.

Students can take classes in a regular classroom setting, at night school, or at our new university high school, in which they can receive an associate degree along with their high school diploma. Another option is our enrichment center, which offers classes in a more relaxed environment with students only attending half days. We wanted our media center offerings to be just as diverse as the other departments.

This was my dilemma at the beginning of this school year. Ben Davis was a new school for me and it represented a change in the age of the students I would work with, as I had previously worked at the elementary level. We have one media specialist and three full time assistants. Our media center's budget is generous, and our administration is very helpful and supportive. Teachers are also willing to collaborate, especially the English and social studies departments.

The following paper is an account of an action research project we did to find out ways to get students reading for recreation. According to The North Central Regional Educational Laboratory (NCREL):

Action research is inquiry or research in the context of focused efforts to improve the quality of an organization and its performance. It typically is designed and conducted by practitioners who analyze the data to improve their own practice. Action research can be done by individuals or by teams of colleagues. The team approach is called collaborative inquiry.

Action research has the potential to generate genuine and sustained improvements in schools. It gives educators new opportunities to reflect on and assess their teaching; to explore and test new ideas, methods, and materials; to assess how effective the new approaches were; to share feedback with fellow team members; and to make decisions about which new approaches to include in the team's curriculum, instruction, and assessment plans.

\section{Need}

The majority of our students are not reading for recreation and yet research shows a correlation between time spent reading and academic benefits. "The more a student reads, the more his or her vocabulary and comprehension increases." (Mckee, 2005) This is why it is necessary for us to design extra-curricula activities such as book clubs. Book clubs give students a chance to meet other students who like to read. Using reading, writing, discussion, 
and instruction, the book club can become a tool that helps students in other academic pursuits.

According to our media center statistics, in the 2006-2007 school year alone, we circulated 18,323 books and materials. We hope to circulate 25,000 books and materials in the upcoming 2008-2009 school year. A circulation of 25,000 books in one school year would be a great improvement and would indicate that students are reading for recreation, as well as for research. Heavy promotion by the media center and word of mouth from students will play a vital role. We will also look at the data at the end of the next two school years to determine if the number of students reading for recreation has continued to increase.

\section{Materials and Methods}

Methods included interviews, surveys (pre/post), questionnaires, student-completed activity sheets, circulation statistics (media center), and Reading Counts reports. Our surveys and interviews were conducted with one hundred students in grades 10-12 randomly. We used qualitative methods to organize the data. The data was collected over a six month period. The data was analyzed by the media specialist in an effort to drive instruction and/or activities and to make sure the clubs were meeting the interests and needs of our diverse group of students.

\section{Literature Review}

It is interesting that there are not a lot of articles about high school book clubs. In searching several educational databases, there were a little over twelve hundred hits for "book clubs." When the search was narrowed for "book clubs and students" the hits went down to hundreds. Entering "book clubs and high school" only produced twenty-one hits. Many of these twenty-one hits focused on specific programs with book clubs and not student-led book clubs, and much of the information was not as useful as I had hoped.

As a result, we had to look at studies done at all levels--elementary, middle, and high school. Taffy Raphael did several studies in the nineties on a program called "Book Club." Although Raphael was speaking about a specific program, there were certain goals that were similar to the goals we wanted for our after-school book club. She stated:

The participants in the Book Club project shared a common vision of the goals of literacy instruction: (a) promoting students' understanding, enjoyment, and choosing to engage in literacy activities; (b) helping students learn to acquire, synthesize, and evaluate information from text; (c) helping students develop a language to talk about literacy. (Raphael, 1991)

Although the students in Raphael's study were of elementary age, these same goals hold true for high school students. In an article in Teacher Librarian entitled, "How I learned to Run a Really Popular Book Club," Hall (2007) suggests that we should not reinvent the wheel. She describes many activities to promote reading that encourages students to come in the media center in droves. She encourages media specialist to "make it fun." This is a great motto. She also mentions incentives which are also a great idea for library media programs. Prizes of Xbox systems and/or pizza parties are sure to bring students in. There should also be refreshments at every meeting. Many students are hungry after school, and it is difficult to concentrate if you are hungry. 
In "Adventures with a High School Book Club" (McKee, 2005), the author says that on the very first meeting of the book club, it is very important to be prepared. "For each meeting, I prepare an agenda and discussion questions, just in case the students forget. At our first meeting, I had the group share their thoughts about reading such as, "What types of books do you read? and "Where do you do most of your reading?"

Studies also pointed out that an up-to-date, relevant media center collection was essential in meeting the needs of students' recreational reading or research activities? According to Curry (1994) "Students at schools with better-funded library media centers tend to achieve higher average reading scores, whether their schools and communities are rich or poor and whether adults in their community are well or poorly educated." Therefore an early question that needs to be answered before deciding on a plan of action to reform media programs is does the media center have the necessary funds to allow for weeding of outdated materials and the purchase of new materials on a regular basis?

Studies also seemed to favor the student-led approach. In classrooms, literature circles which are mini-book clubs often take on the student-led approach. When students direct their own activities, there is a buy-in that can not be duplicated. Daniels (2002) discusses the positive student outcomes for literature circles and the benefits to the school, as well as student achievement:

Many educational researchers today are studying the use of peer-led discussion of literature in promoting positive student outcomes (Almasi, 1995). One type of peer-led literacy intervention is called Literature Circles or sometimes Book Clubs. Harvey Daniels coined the term "literature circles" in the 1990s and continues to be a leading researcher in the area along with many others (Blum et. al., 2002; Daniels, 2002; Goatley, 1995; Pitman, 1997). Much of the research on peer-led interventions examines whether such interventions can meet the needs of diverse learners, and most of the research so far has affirmed this hypothesis (Mathes et. al., 1998; Saenz et. al., 2005; Alvermann et. al., 2006). Alvermann discuss two studies on peer-assisted literacy strategies (Mathes \& Babyak, 2001; Mathes et. al., 2001 as cited in Alvermann). These strategies were found to enhance all students' reading performance, but especially that of lower-achieving students (Alvermann et. al., 2006).

Worthy, Moorman, and Turner (1999) discuss access to materials of interest and the relationship to student achievement. According to these authors:

Research about the importance of interest in learning suggests that students who have access to materials of interest are more likely to read and thus to improve their reading achievement and attitudes. This study examined the reading preferences and access to reading materials of sixth-grade students from three middle schools in a large, ethnically and economically diverse southwestern U.S. school district. Preference surveys and open-ended questions about favorite materials and authors showed that the most preferred materials among students were scary books and stories, comics and cartoons, magazines about popular culture, and books and magazines about sports. Other popular materials were drawing books, books and magazines about cars and trucks, series books, funny books, and books about animals. Comparisons by gender, income, reading attitude, and achievement found more similarities 
than differences. Students' school access to reading materials was examined through a student questionnaire and through interviews with their teachers and librarians. The majority of students obtained reading materials from purchased sources (stores or their homes), rather than schools and libraries. Classrooms ranked a distant last for book sources among even low-income students. Interviews with teachers and librarians, along with classroom visits, showed that the availability of the most popular materials was limited across schools and classrooms.

\section{Implementation}

Moyer (2006) had goals for her Accelerated Reader program that were similar to goals that we wanted in our book clubs. "Three initial goals were to have special education, reluctant readers become more aware of their personal reading habits, increase circulation statistics among special education students, and improve reading grade levels using the Star Reading program." Our goals were to have all reluctant readers become more aware of their personal reading habits, increase circulation statistics in all groups of students, and improve reading grade levels using the Reading Counts program.

Our surveys were answered by about 100 students. Survey questions included:

- What genre of books do you like to read?

- Who is your favorite author?

- How many books have you read for recreation this year?

The complete survey is found in Appendix A

Due to our data collection and analysis and a review of relevant literature and articles, we started five student book clubs and one staff book club. All clubs met after school for one hour and twenty-five minutes, once a week. Students were released in time to catch late activity bus. The book clubs created were The BD (Ben Davis) Reading Club, The Reading Counts Book Club, The Reading Counts Gaming Club, The Battle of the Books Team, and The Graphic Novels Club. These clubs were chosen due to the number of students that wanted to read a certain genre, read independently or wanted the media center to continue incentives similar to the previous media specialist.

The previous media specialist had one book club. It was called the No Club Book Club. This club was designed for students who did not want to be part of a formal club. Students could come in independently and write down what they read in a binder that the media center staff prepared. There were incentives for every ten books read. There were no checks and balances and students were taken at their word. Students could then look through a catalogue with gifts up to thirty dollars and choose one. It was a money drain on the media center because students began to say that they had read ten books every week and then they would select the most expensive gift possible.

This is why I decided on the Reading Counts Incentive Book Club. I also canceled the incentives associated with the No Club Book Club. The students who loved to read but did not want to be part of a formal club continued to participate in The No Club Book Club. The students who were not serious about reading joined other school clubs.

There is much debate in educational circles and educational research on extrinsic motivation (students study for the sake of outside influences such as getting teacher, peer 
praise or for a prize) vs. intrinsic motivation (learning for the sake of learning). Studies have shown that only intrinsic motivation is sustainable. It has been my experience that the students that participate in the book clubs are hooked by the type of books we offer rather than the snacks and prizes. However, due to the prizes, snacks and games they view the media center as "cool" which allow them to come in and "save face" with their peers about joining a book club. The most important factor is getting them to come in the media center and having activities to keep them coming back for more.

Major strategies of the book clubs were: modeling, explaining, discussing, reflecting, questioning, inferring, activating prior knowledge, drawing conclusions, relating, clarifying, and predicting.

The main goal of the was for students to develop a life-long love of reading and to be able to take the information in books and analyze, synthesize, evaluate, and discuss it. Activating prior knowledge was also very important, in order to relate some of the topics back to their own lives. Other activities included choral reading, silent reading, creating puzzles based on plot, and Reading Counts tests for comprehension check. We even played a variation of the American television program, Win, Lose, or Draw, in which contestants draw clues and observers guess what is being drawn, based on the books we read.

We used read-alouds as a method to model reading and to add another dimension to the book clubs. At each meeting students were expected to have read fifty pages of the selected book. In some instances this was not possible due to the other activities students were involved in. I always asked for a show of hands to determine who had completed the readings. If the majority had not read we read about ten pages aloud in unison. This way we did not spoil the book for those who had not had a chance to read. This was especially helpful to students around classroom mid-term and final exams.

Read-alouds for secondary students can be the most rewarding part of a teacher's day, yet many teachers, particularly those at the secondary level, incorrectly believe this strategy is too juvenile for their classes. Read-alouds can be an ideal way to put literacy strategies into content area instruction at all levels (Richardson, 2000).

Another strategy we used was graphic organizers, which help students construct meaning by making connections explicit. The K-W-L chart, an instructional technique, created by D. S. Ogle (1986) was a favorite of the book club members. This technique is used to activate students' prior knowledge. Using the K-W-L chart before we read a new novel, students were able to write what they knew about the book in the first column and what they would like to know in the second column. After we read and finished the activities of the book, they completed the last column with what they learned. They had used this approach in their classrooms and were familiar with it.

According to Fisher (2001), "When students can see evidence of their inquiry and how it has influenced instruction and assessment, they are able to make meaning of knowledge." Using Bloom's taxonomy (1956) I explained to the book club members that all questions on worksheets or questionnaires that they create should cause the members to analyze, synthesize, and apply their knowledge of the books. After modeling what that would look like, students were ready to begin. 
Since the main goal of a book club is to encourage a love of books and regular use of libraries, it is necessary for students to hear about a variety of books. A book talk is one way to accomplish this purpose. A book talk exposes students to books they may have never considered that are outside of their comfort zone. We decided to book talk at least one book at each meeting. Sometimes I would book talk a book, a classroom teacher or one of the students in the book club would conduct the book talk.

In The BD Reading Club, students voted on the books they wanted to read, two at a time. They planned the activities to go with each book. They were expected to have fifty pages read before each meeting. They were all encouraged to create activities for each book, but when someone was absent or forgot to bring an activity, the media specialist always had an back-up activity. This only occurred twice due to absentees from school by the students whose turn it was to conduct the activity.

Snacks were provided at each meeting, with a few pizza parties thrown in once in a while. The media centers' extra curricular account had about \$2000 left over from the previous year allowing us to buy snack and incentives early on. The BD Reading Club started with about twenty-five students but maintained about seventeen regulars.

The books read in The BD Reading Club this year were: Freedom Writers Diary by Erin Gruwell; She Said Yes by Misty Bernall; Flowers in the Attic by V.C. Andrews; Dollmage by Martine Leavitt; and Anansi Boys by Neil Gaiman. We also discussed their favorite book, Twilight, by Stephanie Meyer.

The Reading Counts Incentive Club was a club in which students could read books that had Reading Counts stickers and take a test on them. Most of the books in the media center's collection were Reading Counts books. Students had to have $80 \%$ passing rate to be considered successful. Upon completion of every two books, they would receive local movie tickets and various other incentives. There have been approximately fifty students in The Reading Counts club. This club does not meet formally, students work independently to earn incentives.

The Reading Counts Gaming Club was an additional reward for those students who had been successful with Reading Counts and had received multiple incentives. We had gaming tournaments where students could play video games after school and on their lunch periods. The winners won gift cards at local stores, and pizza and soda was served. Members also received a free book. We had a contest each semester. At the end of the year, the student with the most Reading Counts points won an Xbox 360 gaming system and a series of Xbox 360 games. There were about twenty students in Reading Counts Gaming Club.

In addition, we created a city-wide Battle of the Books competition for high school students. Students read seven books from the Elliott Rosewater list.

The Eliot Rosewater Indiana High School Book Award (Rosie Award) is chosen annually by students across Indiana in grades nine through twelve. Students at participating high schools and public libraries who read any of approximately twenty nominated books are eligible to rate each book they've read. Ballots are available on the Rosie website. The votes are tabulated each May, and the winner is announced (ILFonline.org). 
The seven books were pre-selected by Indianapolis high school media specialists at our annual grant writing meeting. They were: Twilight by Stephanie Meyer; Chanda's Secret by Allan Stratton; / Am the Messenger by Markus Zusak; Crunch Time by Mariah Fredericks; Daniel Half Human and the Good Nazi by David Chotjewitz; A Wreath for Emmett Till by Marilyn Nelson.

Students from area high schools read the seven books all year and then came to Ben Davis for a written test in the morning, which narrowed the teams down to three. In the afternoon the three finalist teams competed in a Jeopardy style test in the auditorium. Each team consisted of five contestants. Each student had a buzzer and could ring the buzzer if they felt they knew the answer to the question posed by the game host. All answers were the title of one of the seven books. Correct answers added twenty points whereas wrong answers took away ten points. Breakfast and lunch was provided for all participants.

The winning team took home a trophy for each contestant and a traveling plaque for their school. The competition aspect brought in some fresh new faces to the media center. The Battle of the Books Team started with twelve students and was narrowed down to a team of five students with two alternates.

With all of the media coverage we received, including one local newspaper article before the event, another local newspaper article after the event as well as our school TV coverage of the event and a thirty minute interview on the school radio station, I am hoping that next year we will have many more students trying to competing in this event.

The Graphic Novels Club, which started later in the school year, was designed to be a place where students could exchange graphic novels. After the media center's initial investment of $\$ 1,500$ to begin a collection, we realized that it would be very difficult to buy all of the books for every series. Therefore, a committee of students helped to select a core collection and through The Graphic Novels Club, students could trade or borrow from each other. The most popular titles were Bleach, Black Cat and Maus. This club maintained about fifteen students; however, each Monday when they meet, there are always several new faces.

Students in all of the clubs were very diverse. We had males and females, sophomores, juniors, and two seniors, Caucasians, African Americans, Asians, Hispanics, one student from the Philippines, and one student from Malawi. Two of the Asian students were new English learners and could not read English very well. Books available on audio or Mp3 were purchased so that all students could benefit from the books. We have over five hundred titles of the most requested books on audio CD and we have about eighty titles in MP3 format. We are continuously adding to both audio formats.

Students were surveyed again at the end of the year to make sure we had met their needs and to make changes if needed for the next year. All of the surveys came back positive. A few had suggestions of different snacks and different incentives. Some will be doable and some will not.

\section{Findings}

After surveying and interviewing students informally, reviewing current studies and articles on book clubs for recreation, a plan of action emerged. At the top of the list was giving students the opportunity to read, make it fun, add incentives, have lots of snacks, have 
fundraisers to pay for all of the activities, and promote, promote, promote. Who knew that if you purchase graphic novels, the books would fly off of the shelves six at a time? We plan to conduct surveys more often to keep the media center abreast on the interest of our students. A suggestion box is located at the circulation desk for wish lists from students and staff.

We kept lots of incentives on hand such as local movie tickets, which we buy cheap at a local credit union. We also have candy for correct answers occasionally. Where does the money come from for all of this? This year the kids sold candy. We also had a book fair at a local bookstore. We have an in-house supply of fund-raising candy at our bookstore, and although only one organization can sell per week, we were able to pick up weeks that other groups did not want. With over 3,000 students in our school, we did really well. Our district is very generous with our library budgets, so we are lucky in that we are able to get the resources that we need. If a student or teacher needs something right away, we occasionally run to our in-house book store or to a local store and buy it.

Also it is important to provide an array of reading materials in various formats so that all students can be successful. Audio books, PDA's, MP3's, and e-books give students who need these formats an equal opportunity to be successful, especially our large population of ENL students.

Students, mostly boys, that I had never seen before, started utilizing the media center. We began arranging other books we thought would be interesting to boys in the area of the graphic novels, and they started reading these novels, also. Next, kids asked us to start a graphic novels club, and we did. This club was populated by word of mouth. It became a swap meet, and students started bringing in their own graphic novels and sharing and exchanging with others. And yes, students were having fun!

Allowing students to lead their own book clubs gave them power and a sense of ownership. Our students decided what book to read and chose their own activities to go with each book. They even chose how long we spent on each book and what snacks we would have at each meeting. Studies back up this method. Creating activities in case students forget their activity is also key if the book club is to run smoothly.

The use of graphic organizers makes connections explicit and helps struggling readers to see a visual representation of the characters and/or plot. Our use of book talks exposed students to a variety of books that were outside of what they would normally read. During The BD Reading Club, many of the Elliot Rosewater List books were book-talked.

The biggest surprise in this project was how the graphic novels took off. The books barely made it to the shelves before there were a line of students, many of whom had never visited the media center before. They were all ready to take six at a time.

The second surprise was how focused the students were in structuring the activities for their book club. Not only did they discuss the books, but they also came up with great activities to go along with each selected book. I also started receiving book reviews on my desk from students who wanted me to know about a "cool book" they were reading.

The benefit for the media center is that now we know many students by first name. Students feel we are more approachable and will talk to us about books they recently read. Our media center is abuzz with activities that help with the overall goal of the school, to 
increase student achievement. And lastly, we are creating life-long readers who will develop vocabularies that will allow them to be successful in all of their academic endeavors.

I have been asked by students to have a poetry club next year. I am looking forward to reading poetry, as I read all of the books from all of the clubs, with one exception. Although I love to read most books, I draw the line at graphic novels. It is definitely a student-led activity. All of the clubs create an environment where the library media center is considered a "cool place" to be and where reading is equally "cool."

But what about our hypothesis of increasing recreational reading at our school, did we make it? The answer is yes. Due to this action research project, we have seen an increase recreation reading and an increase in use of the library by $30 \%$ in six months.

Students still gravitate to the open computers, but now they are actually asking us about authors or titles of books. Our circulation numbers are up, especially in our non-fiction area. Our library staff is even modeling reading by spending at least fifteen minutes each day reading a book or magazine. 


\section{References}

Bloom, B.S. (1956). Taxonomy of Educational Objectives, Handbook I: The Cognitive Domain. New York: David McKay Co Inc.

Burns, Bonnie (1998). Changing the Classroom Climate with Literature Circles. Journal of Adolescent \& Adult Literacy. 42, 124-129.

Fisher, Douglas. (2001) We're moving on up: Creating a School Wide Literacy Effort in an Urban High School. Journal of Adolescent \& Adult Literacy, Oct. pp. 92-101.

Daniels, H. (2002) Literature Circles: Voice and Choice in Book Clubs \& Reading Groups. (2nd ed.) Portland, Maine: Stenhouse Publishers.

Fuchs, D., Fuchs, L. S.,Mathes, P. G. \& Simmons, D. C. (1997) Peer-assisted learning strategies: Making classrooms more responsive to diversity. American Educational Research Journal, 34 (1), 174-206.

Hall, Suzanne. (2007) How I learned to run a really popular book club (and what I learned about its effect on students' reading skills and attitude). Teacher Librarian, 35 (1) pp.32 -37.

Lance, Keith Curry. (1994) The Impact of School Library Media Centers on Academic Achievement. School Library Media Quarterly. 22 (3) Colorado.

McKee, Beverly. (2005) Adventures with a High School Book Club. Library Media Connection, 23 (4) pp. 44-47

Moyer, Mary. (2006) Accelerated Reader Sparks High School Reading Excitement. Knowledge Quest|Snagging Teen Readers: Authors to Zines.35 (1) pp. 34-39.

North Central Regional Educational Laboratory. (2004). Pathways Home. [On-line]. Retrieved May 23, 2008 Available: http://www.ncrel.org/sdrs/areas/issues/envrnmnt/drugfree/sa3act.htm

Ogle, D.S. (1986). K-W-L Group Instructional Strategy. In A.S Palinscsar, D. S. Ogle, B. F. Jones; E. G. Carr (Eds), Teaching Reading as Thinking ( Teleconference Resource Guide, pp. 11-17. Alexandria, VA: Association for Supervision and Curriculum Development

Raphael, Taffy E. (1991) Teaching Literacy through Student Book Clubs: A First-Year Teacher's Experience. Elementary Subjects Center Series No. 41. Center for the Learning and Teaching of Elementary Subjects, MSU, Lansing, MI.

Richardson, J.S. (2000) Read it aloud! Using Literature in the Secondary Content Classroom. International Reading Association.

Worthy, J., Moorman, M., \& Turner, M. (1999) What Johnny Likes to Read Is Hard to Find in School. Reading Research Quarterly, 34 (1), 12-27. 


\section{Further Reading}

Bennett, C.K. (1994). Promoting Teacher Reflection Through Action Research: What do Teachers Think? Journal of Staff Development 15(1), 34-38

Calhoun, E.F. (1994). How to use Action Research in the Self-Renewing school. Alexandria, VA: Association for Supervision and Curriculum Development.

Eisenburg, Michael B. and Robert E. Berkowitz. "Big6: An information Problem Solving Process." The Big6: Information Literacy for the Information Age. May 12, 2005.

L Galda, R Beach. (2001) Response to Literature as a Cultural Activity. Reading Research Quarterly 36 (1) pp. 64-73.

Langhorst, Eric. (2007) After the Bell, Beyond the Walls. Educational Leadership 64 (8) pp.74-78.

Kaston, Wendy; Wilfong, Lori G. (2005) Encouraging Independent Reading with Ambience: The Book Bistro in Middle and Secondary School Classes. Journal of Adolescent \& Adult Literacy; May pp. 656-664.

Littlejohn, Carol. (2006) The Oprah Revolution: Book Clubs in Library Media Centers Library Media Connection. Nov/Dec pp. 28-29.

Lingo, Sandra. (2007) The All Guys Book Club: Where Boys Take the Risk to Read. Library Media Connection April/May 2007.

Locker, Ben (2002) Reading Clubs. Literacy Today. March p. 15.

Malanchuk, Iona R. Academic Librarians Organize a Sixth-grade Reading Club. Young Adult Library Services. 4 (4) pp. 13-18.

Mckee, Beverly. (2005) Adventures with a High School Book Club. Library Media Connection. January. pp. 44-46.

McKenna, M., \& Kear, D. (1990) Measuring attitude towards reading: A new tool for teachers. Reading Teacher, 43 (9), pp. 626-639.

Ryan, R; Deci, E. (1996).When Paradigms Clash. Comments on Cameron and Pierce's Claim that Rewards do not Undermine Intrinsic motivation. Review of Education Research. 66, pp .33-38.

Seitz, Ingrid; Goodson, Lori Atkins (2005) Student Book Clubs: Improving Literature Instruction in Middle and High School. Journal of Adolescent \& Adult Literacy; 50 (1) pp.86-88.

Welldon, Christine. (2005) Addressing the gender gap in boys' reading. Teacher Librarian; April 32 (4) pp. 44-45. 


\section{Biographical Notes}

Kathy Hicks-Brooks is currently the head media specialist at Ben Davis High School in Indianapolis, Indiana. She has two teenage sons. She holds national board certification in library media.

\section{Statement of Originality}

This statement certifies that the paper above is based upon original research undertaken by the author and that the paper was conceived and written by the author(s) alone and has not been published elsewhere. All information and ideas from others is referenced. 


\section{Appendix A}

Pre-Program Survey Administered to Randomly Selected Students in Grades 10-12 September 2008

In order for us to purchase books you will read, we would like you input. Please fill out the following form and leave it in the box at the circulation desk.

1. Name

2. Grade

$$
\text { Not required }
$$

3. Male Female check one

4. What genre of books do you like to read?

5. Who is your favorite author?

6. How many books have you read this year?

7. Do you read for recreation?

8. Do you think reading is a "cool" activity?

9. Would you be interested in joining a book club?

10. What books would you suggest we buy? Name/Author 


\section{Appendix B}

Pre-Program Survey Results

September 2007

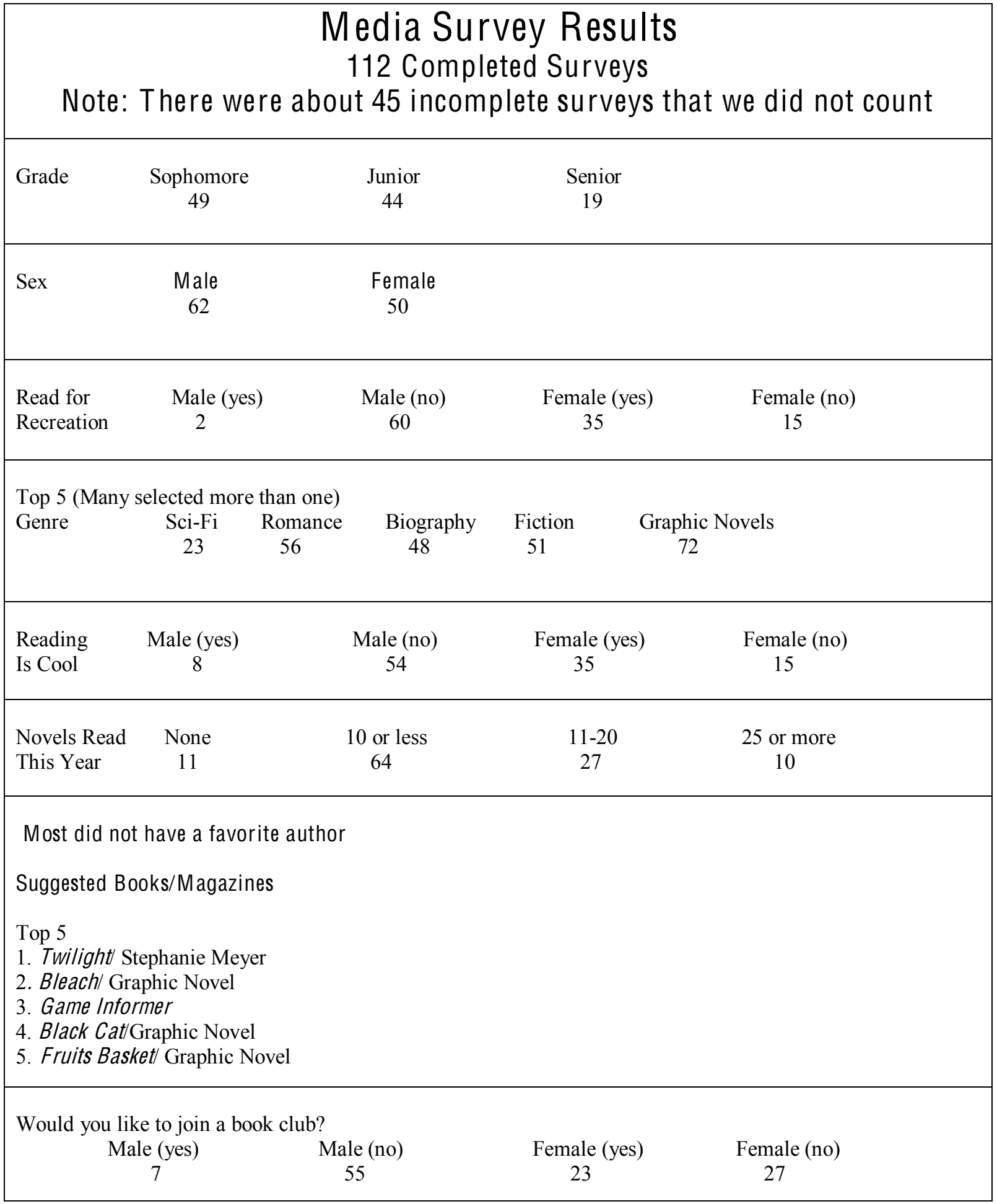




\section{Appendix C}

Sample Ben Davis Reading Club Agenda

February 2008

Ben Davis Reading Club Agenda

February 20, 2008

\section{Book Selection}

Dollmage by Martine Leavitt

3:05 - 3:15 Turn in candy money

3:15 -3:30 (Whole group) Review of the last 50 pages of Dollmage

3:30 - 3:45 (Whole group) Take Reading Counts Quiz on Dollmage

3:45 - 4:00 (Small groups) Activity - shared by S. Moyer

4:00 - 4:15 Snack and discussion of upcoming field trip

4:15 - Late bus pass

4:25 Dismissal

Agenda for next meeting due by $2-25-08$ 